Bulletin of Taras Shevchenko National University of Kyiv. Series "Psychology". № 1(13), pp. 38-41 (2021) УДК 159.923

DOI: https://doi.org/10.17721/BSP.2021.1(13).7
ISSN 1728-3817

(C) Taras Shevchenko National University of Kyiv,

Publishing and Polygraphic Center "Kyiv University", 2021

Anton Kurapov, PhD (Psychology), Assist. Prof. ORCID ID: 0000-0002-1286-9788;

Aleksandra Balashevych, Student ORCID ID: 0000-0002-4865-3487; Hanna Tsurikova, Student

ORCID ID: 0000-0003-1744-0128

Taras Shevchenko National University of Kyiv, Kyiv, Ukraine

\title{
COMPLEX SOUND'S PITCH AND TEMPO PERCEPTION: PSYCHOLOGICAL AND INSTRUCTIONAL FEATURES
}

The study investigates features of complex sound's pitch and tempo perception depending on instructional set presence via the Likert scale and WAM test (wellbeing, activity, mood). Influence of objective complex sound characteristics (pitch and tempo) on a subjective evaluation of a music fragment, as well as the influence of instructional set (prior informing of a participant about objective differences between music fragments) on a subjective evaluation of a music fragment, were explored. The study looks at how people of different genders, whether they know how to play an instrument or have had musical education, perceive music. It was discovered that high pitch music was embraced as more fun, bright, light, and indecisive. Music with a higher tempo was also perceived as carefree, which is subjectively evaluated as less heavy and more fun. People with musical education background notice more differences between fragments with various pitches and tempos, specifically, they are capable of differentiating pitch and tempo changes better. In general, the study has shown that it is possible to manipulate objective characteristics of a complex sound in order to create widely acceptable subjective and psychological interpretation.

Keywords: pitch and tempo perception, complex sound, music, psychoacoustics, music psychology.

Problem Statement. Divided into various musical cultures across the whole world, music plays an important role in human life and influences different domains of it. Today, the amount of audio information in people's daily routines has increased significantly, and this information has a considerable impact on a person's emotional state. Music psychology today is based on the findings of acoustics, philosophy, ethnomusicology, musicology, and other scientific studies. Lately, it can be seen that the interest in human musicality and in the way human brain handles musical information has been raised among scientific disciplines studying neuronal features of perception. Philosophy analyses music from different perspectives too, trying to understand it as a human phenomenon. As a result, music is viewed as a complex phenomenon with a variety of features that definitely have a capability of being psychologically interpreted.

The physical feature of sound as a lengthwise wave that spreads through the air fully defines and describes the sound itself. Each individual perceives sound differently, depending on personality traits, psychological or biological factors, in particular individual experience, presence or lack of inborn absolute pitch, attitude to perceived music, etc. However, there are two objective sound features, pitch and tempo, and they allow to look at subjective audial stimuli interpretation in more detail.

The primary goal of this study is to investigate aspects of complex sound pitch and tempo perception based on instructional set using the Likert scale. A traditional experiment design was used, with an experimental and a control group. This study will increase understanding of human subjective perception of pitch and tempo in music, which may aid in the use of music for therapeutic purposes, since psychological interpretation of music is not unique and manipulation with objective characteristics of the complex sound would allow to create very precise subjective evaluation, common for the majority of people.

Literature Review. The perception of music is studied at the intersection of many sciences. There are two approaches to music description: physical and psychological. Physical description of music is made within the framework of physical acoustics [3]. Physical perspective $[11,19]$ has its advantages that include accurate and objective explanation of each studied phenomenon.
Nonetheless, its main disadvantage is presented in the overall mathematical difficulty and specific descriptions that are rather hard to understand without having a specialized mathematical or physical educational background.

The perception of music was also investigated in the relation to individual psychological characteristics of participants [2, 5, 8, 25]. Music perception features were explored from a psychological and biological standpoint [24]. Some aspects of sound perception in relation to timbre [14], rhythm, and tempo [15] and a person's sociocultural surroundings $[18,23]$ were investigated. It was discovered how classical music affects the cognitive domain of children [7] and human emotions [12, 13, 22]. All of these approaches are often combined in order to describe researched phenomenon from a number of angles.

From a physical perspective, music is a sequence of sounds and is characterized as a combination of independent physical parameters. If these parameters are set, further sound spread is determined and can be accurately measured and anticipated. However, this kind of measurement requires sound spread circumstances and environment to be defined, which complicates the process $[11,19]$. This is the reason why more common and less strong notions that describe music in less detail, but simpler and more convenient are operated.

Music perception depends on individual perception characteristics of each listener, and from characteristics of the melody itself, and has a long history of study. Psychoacoustics fundamental knowledge is used in creating various technologies such as hearing aids, room acoustic design etc. Psychoacoustics also does studies of statistical reactions of respondents to sound as a stimulus and considers both physical and psychological features of sound perception [2, 5, 8, 14, 15]. This is one of the scientific areas that views complex sound in the combination of exclusively physical and exclusively psychological characteristics.

The power of music's influence on people results from its sociocultural meaning. It depends on the function music has (artistic, ritual, domestic, therapeutic), as well as its perceptional features [18, 23]. Most people prefer music that correlates with their current psychic emotional state [18]. Representatives of social sciences state that this fact evidences that people try to understand themselves, their 
relationships with the outer world through music. That is, music's psychic emotional influence on a person can be seen in two ways: firstly, as a change of sense of self (attempt to understand inner self), secondly, as a change of psychic emotional state itself, thirdly, as a change of personality's psychic development [23]. Sound is perceived by a person directly, as well as indirectly by affecting listener's sense of self and mood respectively.

Methodology. Considering the strong connection between music and psychology, it was assumed that there is dependence between subjective evaluation of the complex sound and its physical features. In other words, this research is aimed at answering the following questions:

1. How do objective features of complex sound (pitch and tempo) affect subjective evaluation of music fragment?

2. How does instructional set (prior informing of a participant about objective differences between music fragments) affect subjective evaluation of a music fragment?

In the study, three fragments of a musical piece (Gliere Prelude in D Flat Major, Op. 43 No. 1) were proposed. The first fragment was played one octave higher than the original sample, i.e., it was between first and second octaves, tempo was equal to $141 \mathrm{bpm}$. The second one had the original pitch and was played within the small and second octave, tempo was equal to $128 \mathrm{bpm}$. The last fragment had the lowest pitch and was within big and small octaves, its tempo was the slowest $-150 \mathrm{bpm}$.

The sample consisted of 86 participants. It included 30 men $(34,9 \%)$ and 54 women $(62,8 \%)$. There were 2 $(2,3 \%)$ respondents who identified their sex as "Other". In general, the sample consisted of participants aged from 16 to 80 . Basing on Erikson's age classification, most of the respondents were teenagers and young adults (1220 years old), adults (20-25 years old) and middle-aged people (25-60 years old). There also were participants of a late maturity period (more than 65 years old). Most of them (fig. 2) had never had musical education (58 people, $67,4 \%$ ) or had elementary musical education. Among respondents, $28(32,6 \%)$ stated they know how to play an instrument. Participants had music tastes in a wide spectrum of musical genres, including rock, metal, pop and classical music. The sample covers a wide range of age, musical education level and likings in music.

Results. Participants were proposed to evaluate musical fragments by the following features: "sad-fun", "decisive-indecisive", "anxious-calm", "bright-dark", "boringexciting", "light-heavy".

Outcome measures show that women assess the first fragment as more decisive, bright and exciting than men. As for the third fragment, women perceive it as less fun and calm, but at the same time, less dark, than men. Thus, it can be concluded that women perceive music more emotionally than men (Table 1).

Differences in different fragments perception by men and women

\begin{tabular}{|c|l|c|c|c|}
\hline Fragment & Features & $\boldsymbol{p}$ & $\boldsymbol{V}$ & $\begin{array}{c}\text { Difference } \\
\text { Rank }\end{array}$ \\
\hline 1 & indecisive & 0,014 & 558 & 13,07 \\
\hline 1 & dark & 0,030 & 596 & 11,09 \\
\hline 1 & exciting & 0,02 & 506 & $-15,74$ \\
\hline 3 & fun & 0,011 & 556 & 13,17 \\
\hline 3 & calm & 0,001 & 454 & 18,46 \\
\hline 3 & dark & 0,047 & 608 & 10,47 \\
\hline
\end{tabular}

The next step was determining the differences in fragment perception depending on playing a musical instrument skill. Participants who knew how to play an instrument perceive the second fragment as funnier; the third fragment was perceived as calmer. The second and the third fragments were less heavy for players: it is easier for them to describe music fragments. The second one is more fun and less heavy for them, because it has an original pitch that was created by the author. The third one has a higher tempo, which is why it can seem not so anxious and heavy, since high tempo music can be associated with lightness and carelessness (Table 2).

Table 2

Differences in different fragments perception depending on playing a musical instrument skill presence

\begin{tabular}{|c|l|c|c|c|}
\hline Fragment & Features & $\boldsymbol{p}$ & $\boldsymbol{V}$ & $\begin{array}{c}\text { Difference } \\
\text { Rank }\end{array}$ \\
\hline 2 & fun & 0,022 & 582 & 12,18 \\
\hline 3 & calm & 0,001 & 452 & 19,07 \\
\hline 2,3 & heavy & $<0,027$ & $516-584$ & $15,67-12,07$ \\
\hline
\end{tabular}

Differences in fragment perception depending on musical education presence were found. Participants with musical education perceive the first fragment as more exciting, calm, as well as less heavy, than those without musical education. The second fragment people without education hear as less fun, but also less heavy, than people with education. The third fragment is perceived as heavier by people with musical education. They notice more differences between fragments with different pitch and tempo (Table 3).

Table 3

Differences in different fragments perception depending on musical education presence

\begin{tabular}{|c|c|c|c|c|}
\hline Fragment & Features & $p$ & $\boldsymbol{V}$ & $\begin{array}{c}\text { Difference } \\
\text { Rank }\end{array}$ \\
\hline 1 & calm & \multirow{3}{*}{$<0,005$} & \multirow{3}{*}{$262-300$} & \multirow{3}{*}{$16,16-18,92$} \\
\hline 1 & exciting & & & \\
\hline 2 & fun & & & \\
\hline 1 & dark & \multirow{2}{*}{$<0,010$} & \multirow{2}{*}{$312-322$} & \multirow{2}{*}{$-14,56--15,29$} \\
\hline 3 & heavy & & & \\
\hline 2 & heavy & 0,000 & 248 & $-19,94$ \\
\hline
\end{tabular}

To identify the accordance of mathematical statistics methods, it is necessary to check the sample for normal distribution. In order to complete that task, two statistical criteria were used: the Kolmogorov-Smirnov test and Mann-Whitney U-test. Yet, wellbeing, activity and mood test results have similar distributions.

Differences in the relevant mental state depending on participants' sex were found. It was also revealed that there is a small effect of sex on "WAM" test results. Statistical research on the reliance of "WAM" test results on the presence of instructional set was conducted. Well-being test results were found to be smaller when the set was absent. On the contrary, activity results were higher in the presence of the set. It can be said that in set presence, the average value of the mood category was higher too. Yet, the difference between average values was significantly higher than standard deviation.

Spearman's rank correlation coefficient was used in order to determinate the correlation between evaluating a fragment and a current psychic state. Average measurements of measured music features are depicted in Fig. 1. Significant statistical correlations were found while determining the link between variables.

Looking into well-being, it can be assumed that the better a person feels, the less fun and calm the first fragment seems to him/her. There is an inverse correlation between the second fragment and well-being in the "calm" characteristic, but because its pitch is one octave lower (original pitch fragment), it seems to be more fun. There is an inverse correlation in the "exciting" characteristic of the third fragment, that has the lowest pitch. If a person has good well-being, then the first fragment seems brighter, which is expected, because it has the highest pitch. The third fragment is perceived as more indecisive as its style suggests. 
People with higher level of activity measurements appraised the first fragment as "decisive" and "anxious". It can be explained by tempo. The first fragment has a high tempo and was played in uppercase, so people with high activity perceive quick music as decisive, but also as anxious and turbulent. Music can be a factor of higher emotional dynamic and ruin the balance of those people. In addition, these participants characterize the second fragment as anxious, but in the meantime light, and the third one as not really exciting.

Judging by results interpretation, it can be concluded that depending on well-being, activity, and mood, people perceive music as more decisive, if it has a higher tempo. The first fragment is the highest and was assessed as the funniest, the most indecisive, the calmest, and the most exciting. The second one of the original pitches was evaluated between the first and the third and as increasingly calm, exciting and heavy. The third one - the lowest - was described as fun, indecisive and calm, which makes sense: people perceive higher pitch music as funnier and lighter (Fig. 1).
There is a difference in the fragment perception between participants who were given the instructional set and those who did not have one (Fig. 2). Considering the influence of instructional set on music fragments perception, the following tendency can be seen: respondents given the set perceive the fragments as less exciting, compared to those who were not given the set, and this phenomenon does not depend on music tempo and pitch. The presence of set made participants less sensitive to the differences between the fragments. This feature occurs in every fragment's characteristics except for "exciting". The biggest difference appeared between such characteristics as "calm" and "exciting". The set presence makes fragments with middle pitch funnier, as well as makes lower pitch fragments less anxious. The smallest difference between evaluating music fragments with and without the instructional set happened to be in the "indecisive" characteristic. It shows that individuality of subjective perception of a fragment almost doesn't affect assessment of its decisiveness (Fig. 2).

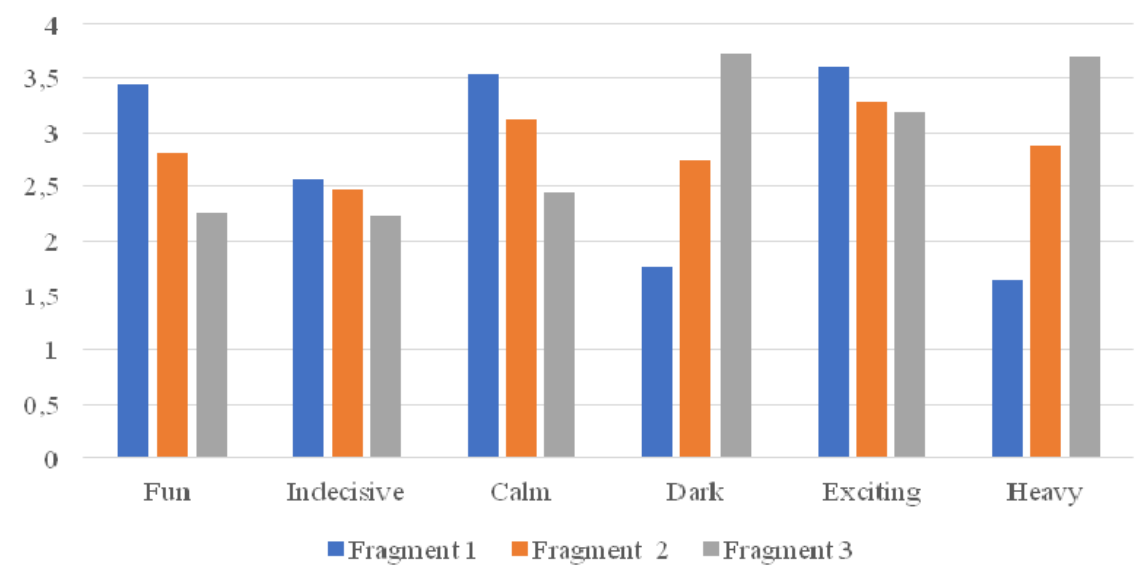

Fig. 1. Average measurements of fragments evaluated by different criteria

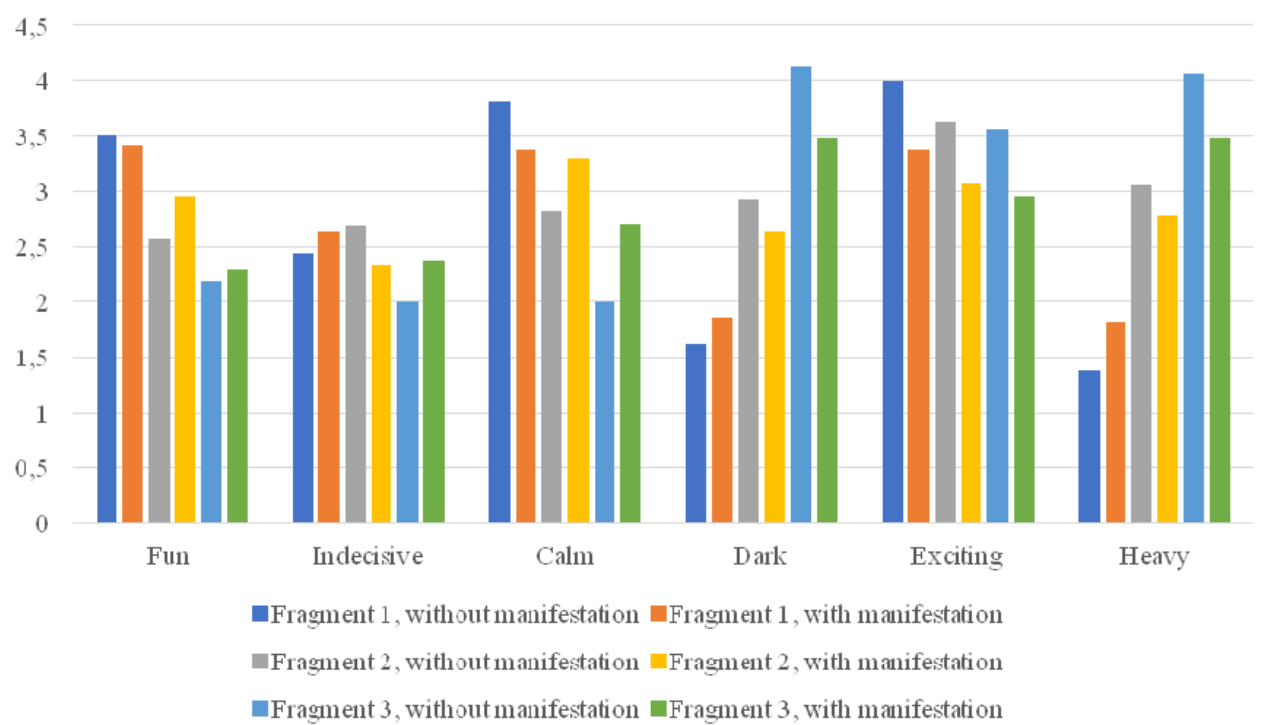

Fig. 2. Average measurements of fragments evaluated by different criteria depending on presence of the instructional set

The influence of the instructional set presence on subjective perception of music fragments with different pitch and tempo was investigated. It was found, that there is a significant difference in perception of fragments with different pitch with or without the instructional set. The biggest difference was in such fragment characteristics as anxiety and excitement.
Discussion. The results show that women, on average, perceive music a little more emotionally than men. Regarding the perception of melodies of different heights, it was found that melodies in higher registers are perceived as carefree, exciting and light, in contrast to melodies in lower registers. The lower-case music (upper and lower octaves) sounds majestic and admirable, and when a person is in good well-being, he can prefer lower tones. People with a 
music education sense the difference between passages with different heights and tempos better. From the interpretation of the results, it can be concluded that people, regardless of well-being, activity and mood, perceive music that is faster in tempo as more decisive.

Objective characteristics of complex sound (pitch and tempo) affect the subjective assessment of a music fragment. High-profile music is perceived as more cheerful, light, bright and indecisive. High-tempo music is also perceived as more carefree, i.e., less heavy and more fun. Thus, indeed, the subjective perception of music can be changed by varying the physical and acoustic properties of the melody.

The presence of an instructional set, i.e., informing the respondent in advance about objective differences in musical passages, influences the subjective assessment of music. Respondents given the set perceive music as less exciting, compared to those who do not have one regardless of the tempo and pitch of the melody. The presence of the set makes the subjects less sensitive to the difference between the music. At the same time, the biggest difference for the participants with and without the set was in such characteristics as anxiety and excitement.

The set presence makes music played in the middle registers more fun, and also significantly reduces the anxiety of music that has low registers. For the "indecisive" characteristic, the difference in characteristics with and without the manifestation was the smallest, indicating that the individual's subjective perception of music has almost no effect on the assessment of its decisiveness. Thus, answers to research questions were obtained.

An important role in the perception of music is also played by situational indicators of a person's state in which he listens to the music, as well as such criteria as gender, musical education and skill to play a musical instrument. People, regardless of their well-being, activity and mood, perceive music that is faster in tempo as more decisive. Women rate higher melodies as more decisive, bright and exciting, compared to men. Melodies in low registers are perceived by women as more disturbing and less cheerful and dark. In general, women perceive music more emotionally than men. It is easier for people who know how to play musical instruments to characterize musical passages. Respondents with the skills of playing musical instruments perceive music of original height as more fun and not so difficult. People with a music education see more difference between passages with different heights and tempos.

The study of the music psychology various aspects provides broad prospects for further research. Another example is the study of music perception in marketing and political campaigns. By understanding how music affects different segments of the population, it is possible to influence people's preferences. By examining a wider sample, for example, different ethnic or social groups, it is possible to identify how people of different countries, or different ages or social backgrounds perceive music, which can give a deeper and more thorough understanding of the subjective perception of music.

References

1. About the hearing, ear structure. Vuhosluh.com.ua. Retrieved 2 April 2021, from http://vuhosluh.com.ua/prosluh. 2021

2. Aldoshina I. Psychoacoustics basics. Sound engineering. M. : 1999. $200 \mathrm{p}$.

3. Ananiev B. G. The tasks of art psychology. Human: Image and essence. Humanitarian aspects. 2001. (1). 251-261.

4. Asafiev B. V. Musical form as a process. M. : Progress, 1971. $341 \mathrm{p.}$

5. Blomstedt T. Psychoacoustics: An Introduction to Sonic Activism. SpB: Piter, 2014. 231 p.

6. Bochkarev L. L. Psychology of musical activity. 1997

7. Črnčec R., Wilson S. J., Prior M. The cognitive and academic benefits of music to children: Facts and fiction. Educational Psychology. 2006. T. 26. № 4. P. 579-594.

8. Fastl H. Psycho-acoustics and sound quality. Communication acoustics. Springer, Berlin, Heidelberg, 2005. P. 139-162.

9. Gotsdiner A. L. Musical psychology. M. : International Academy of Pedagogical Sciences. 1993

10. Human Hearing Range - What Can We Hear?Widex.ru Retrieved 8 April 2021, from https://www.widex.ru/ru-ru/blog/hearing-range. 2018.

11. Irisov A. S. Sound and music. Ripol Classic. 2013.

12. Juslin P. N., Västfjäll D. Emotional responses to music: The need to consider underlying mechanisms. Behavioral and brain sciences. 2008. T. 31. №. 5. C. 559-575.

13. Konečni V. J. Does music induce emotion? A theoretical and methodological analysis. Psychology of Aesthetics, Creativity, and the Arts. 2008. T. 2. № 2. C. 115

14. Leskov A. I. Timbre as a semantic factor in the perception of musical meaning. Bulletin of the Russian State Pedagogical University. A. I. Herzen. 2014.

15. Moelants D., McKinney M. Tempo perception and musical content: What makes a piece fast, slow or temporally ambiguous. Proceedings of the 8th International Conference on Music Perception and Cognition. 2004. C. $558-562$.

16. Nazaikinsky E. V. On psychology of music perception. 1972.

17. Nazaikinsky E. V. Sound world of music. 1988.

18. North A., Hargreaves D. The social and applied psychology of music. OUP Oxford, 2008

19. Riman H. Music dictionary. A-Z. Directmedia, 2013

20. Rubinshtein S. L. Fundamentals of General Psychology-St. Petersburg: Publishing House "Peter". Series "Masters of Psychology". 2000.

21. Schellenberg E. G. Long-term positive associations between music lessons and IQ. Journal of educational psychology. 2006. T. 98. № 2. C. 457

22. Scherer K. R. Vocal communication of emotion: A review of research paradigms. Speech communication. 2003. T. 40. №. 1-2. P. 227-256.

23. Starcheus M. S. Secrets and myths of the emotional and psychological impact of music on a person. 2007

24. Tan S. L., Pfordresher P., Harré R. Psychology of Music: From Sound to Significance Second Edition. Routledge, 2017.

25. Yost W. A. Psychoacoustics: A brief historical overview. Acoustics Today. 2015. Т. 11. № 3. С. 46-53.

Надійшла до редколегіï 21.02.21 Рекомендована до друку 14.06.21

Антон Курапов, канд. психол. наук, асист.

ORCID ID: 0000-0002-1286-9788;

Балашевич Олександра, студ.

ORCID ID: 0000-0002-4865-3487;

Цурікова Анна, студ.

ORCID ID: 0000-0003-1744-0128

Київський національний університет імені Тараса Шевченка, Київ, Україна

\section{ОСОБЛИВОСТІ СПРИЙНЯТТЯ ВИСОТИ ТА ТЕМПУ КОМПЛЕКСНОГО ЗВУКУ ЗАЛЕЖНО ВІД НАСТАНОВИ}

Представлено результати дослідження особливостей сприйняття висоти та темпу комплексного звуку залежно від інструкційної настанови за допомогою методу семантичного диференціалу, а також методики САН (самопочуття, активність і настрій). Досліджено вплив об'єктивних характеристики комплексного звуку (висота й темп) на суб'єктивну оцінку музичного уривку, а також вплив наявності настанови (попереднє інформування респондента про об'єктивні відмінності в музичних уривках) на суб'єктивну оцінку музичного уривку. Було проаналізовано, як люди різної статі, з навичками гри та музичних інструментах та без них, а також із наявною або відсутньою музичною освітою сприймають музику. Визначено, що музику у високих реаістрах сприймають як більш веселу, легку, світлу та нерішучу. Музику з високим темпом також сприймають як більш безтурботну, тобто менш важку та більш веселу. Наявність настанови робить досліджуваних менш сприятливими до відмінностей між музикою. Люди з музичною освітою бачать більше відмінностей між уривками з різною висотою та темпом.

Ключові слова: сприйняття висоти та темпу, комплексний звук, музика, психоакустика, психологія музики. 